\title{
GAMBARAN INTERAKSI OBAT PENYAKIT JANTUNG KORONER DENGAN SINDROM METABOLIK PADA PASIEN RAWAT JALAN DI RS TK II DR. SOEPRAOEN MALANG
}

\author{
Rakhmadani Gadis Aprilianti ${ }^{1}$, Beta Herilla Sekti ${ }^{2}$, Lilik Nur Hidayati ${ }^{3}$ \\ 1,2,3 Institut Teknologi, Sains, dan Kesehatan RS dr Soepraoen Malang \\ Email Korespondensi : gadis.aprilianti23@gmail.com
}

\begin{abstract}
ABSTRAK
Interaksi obat merupakan efek dari suatu obat yang disebabkan jika terdapat dua obat atau lebih yang saling berinteraksi dan mempengaruhi respon tubuh terhadap pengobatan. Tujuan dari penelitian ini adalah untuk mengetahui gambaran interaksi obat penyakit jantung koroner dengan sindrom metabolik pada pasien rawat jalan penyakit jantung koroner. Penelitian ini merupakan penelitian deskriptif menggunakan metode observasional cross-sectional dengan pengamatan retrospektif pada bulan Oktober Desember 2020. Pengambilan data pasien diperoleh dari data rekam medis pasien dengan teknik pengambilan sampel yaitu purposive sampling dengan kriteria inklusi sebanyak 89 pasien yang diambil sebagai sampel. Analisis data menggunakan aplikasi MEDSCAPE dan drugs.com. Sebanyak 82 resep berpotensi mengalami interaksi obat dimana tingkat signifikansi interaksi obat paling banyak yaitu level moderate $(81,48 \%)$ diantaranya yaitu aspirin dengan candesartan dan bisoprolol dengan amlodipine. Interaksi obat paling banyak yaitu interaksi antara aspirin dengan bisoprolol yang tergolong interaksi minor $(17,74 \%)$. Kndungan obat yang paling sering digunakan yaitu bisoprolol $(22,18 \%)$ dan golongan obat paling sering digunakan adalah beta blocker.
\end{abstract}

Kata kunci : Interaksi Obat, Penyakit Jantung Koroner 


\title{
OVERVIEW DRUG INTERACTIONS OF CORONARY HEART DISEASE WITH METABOLIC SYNDROME ON OUTPATIENT IN DR. SOEPRAOEN HOSPITAL MALANG
}

\begin{abstract}
Drug interaction is the effect of a drug that is caused when there are two or more drugs that interact and affect the body's response to treatment. The method used in this study is a descriptive study using a cross-sectional observational method with retrospective observations in October - December 2020. Patient data collection was obtained from patient medical records using a purposive sampling technique with inclusion criteria. A total of 89 patients were taken as samples. Data analysis using MEDSCAPE and drugs.com applications. A total of 82 prescriptions have the potential for drug interactions, where the most significant level of drug interaction is moderate level (81.48\%, these include aspirin with candesartan and bisoprolol with amlodipine. The most drug interaction is the interaction between aspirin and bisoprolol which is classified as a minor interaction (17.74\%). The most frequently used type of drug is bisoprolol (22.18\%) and the most frequently used drug class is beta blocker.
\end{abstract}

Keywords : Drug Interaction, Coronary Heart Disease

\section{PENDAHULUAN}

Penyakit Jantung Koroner (PJK) bukanlah penyakit menular namun jumlahnya semakin hari semakin meningkat baik di dunia maupun di Indonesia. Diperkirakan penyakit jantung koroner pada tahun 2020 menjadi pembunuh pertama tersering yakni 36\% dari seluruh kematian, angka ini dua kali lebih tinggi dari angka kematian akibat kanker. Di Indonesia dilaporkan PJK merupakan penyebab utama dan pertama dari seluruh kematian, yakni sebesar 26,4\%, angka ini empat kali lebih tinggi dari angka kematian yang disebabkan oleh kanker 6\% (Perhimpunan Dokter Spesialis Kardiovaskular, 2015). Penyakit jantung koroner merupakan penyebab paling banyak yaitu $60-75 \%$, diikuti penyakit katup $10 \%$, dan kardiomiopati 10\% (Imaligy, 2014).

https://doi.org/10.33759/jrki.v4i1.222 
Interaksi obat dapat ditimbulkan dari berbagai proses, seperti perubahan pada farmakokinetik obat yang meliputi absorpsi, distribusi, metabolisme, dan ekskresi obat. Interaksi obat juga dapat ditimbulkan dari sifat farmakodinamik obat tersebut seperti efek samping yang serupa atau yang berlawanan dimana efek samping masing-masing obat akan saling mengganggu dan kemungkinan akan terjadi hal yang tidak diinginkan sehingga berpotensi membahayakan dan memberikan efek yang signifikan. Interaksi obat dapat menyebabkan penurunan efek obat sehingga hasil terapi yang di dapat tidak maksimal. Masalah interaksi obat harus diperhatikan bagi tenaga kesehatan terutama di bidang kefarmasian, agar dapat mencegah timbulnya resiko morbiditas dan mortalitas dalam pengobatan pasien (Hanutami, 2019).

Faktor yang dapat memperparah penyakit jantung yakni kejadian interaksi obat. Selain penyakit jantung koroner, biasanya pasien memiliki penyakit penyerta lain sehingga dalam terapinya membutuhkan berbagai macam obat. Penggunaan terapi dengan berbagai macam obat sekaligus juga dapat mengakibatkan adanya interaksi obat. Interaksi obat merupakan efek dari suatu obat yang disebabkan bila terdapat dua obat atau lebih yang saling berinteraksi dan mempengaruhi respon tubuh terhadap pengobatan (Kuncoro \& Yanti, 2019) .

Terdapat penelitian yang telah dilakukan mengenai interaksi obat. Salah satunya yaitu Evaluasi Interaksi Obat Jantung Koroner Pada Pasien Rawat Inap Di Rumah Sakit Umum Kabupaten Tangerang 2017, yang telah dilakukan oleh Nur'aini, dkk., (2019) menunjukkan bahwa pasien PJK banyak terjadi pada laki-laki $(72,80 \%)$ pada usia 45-55 tahun (38,04\%). Interaksi obat pasien PJK yang berpotensi sebanyak $89,13 \%$ dengan interaksi paling banyak aspirin dengan bisoprolol $17,80 \%$ dan klasifikasi paling banyak level moderat $72,2 \%$.

Interaksi obat dapat menyebabkan penurunan efek obat sehingga hasil terapi yang di dapat tidak maksimal. Masalah interaksi obat harus diperhatikan bagi tenaga kesehatan terutama di bidang kefarmasian, agar dapat mencegah timbulnya resiko morbiditas dan mortalitas dalam pengobatan pasien. Berdasarkan uraian diatas, Penyakit Jantung Koroner merupakan penyakit yang memerlukan penanganan khusus. Hal tersebut yang

https://doi.org/10.33759/jrki.v4i1.222 
mendorong peneliti untuk melakukan penelitian mengenai gambaran interaksi obat penyakit jantung koroner dengan sindrom metabolik pada pasien rawat jalan di RS Tk II dr. Soepraoen.

\section{METODE PENELITIAN}

\section{MATERIAL}

Penelitian ini merupakan penelitian deskriptif menggunakan metode observasional cross-sectional dengan pengamatan retrospektif selama 3 bulan pada bulan Oktober - Desember 2020. Pengambilan data pasien diperoleh dari data rekam medis pasien di poliklinik Jantung $\mathrm{RS} \mathrm{Tk}$ II $\mathrm{dr}$. Soepraoen Malang. Populasi dalam penelitian ini yaitu semua data rekam medis pasien rawat jalan penyakit jantung koroner yang melakukan pengobatan di Poliklinik jantung RS Tk II dr. Soepraoen Malang. Sampel diambil menggunakan teknik purposive sampling dengan kriteria inklusi, sebagai berikut:

1. Pasien dengan diagnosa jenis penyakit jantung koroner.

2. Pasien yang menerima obat dengan riwayat penyakit sindrom metabolik seperti diabetes mellitus, hipertensi, dan kolesterol.

3. Pasien dengan umur $\geq 40$ tahun.
4. Pasien yang diresepkan $\geq 2$ macam obat yang termasuk sindrom metabolik dan penyakit jantung koroner secara bersamaan.

5. Pasien yang menerima obat jantung koroner di RS Tk II dr. Soepraoen periode Oktober - Desember 2020.

Perhitungan sampel dihitung menggunakan rumus slovin yang diketahui jumlah pasien tiap bulan berkisar \pm 38 pasien. Data yang akan diambil yaitu periode Oktober Desember 2020 adalah 38 x $3=114$. Hasil perhitungan populasi pasien dalam 3 bulan $(\mathrm{N})=114$ pasien dengan tingkat kepercayaan 5\% maka sampel yang digunakan sebanyak 89 pasien dengan kriteria inklusi. Terdapat 2 variabel pada penelitian ini yaitu, variabel bebasnya jumlah obat yang diterima pasien dan penyakit penyerta (sindrom metabolik). Untuk variabel terikatnya adalah kejadian interaksi obat. Tahapan dalam pengolahan data yaitu editing, entry data, dan tabulating. Data yang didapatkan dianalisis menggunakan aplikasi yaitu MEDSCAPE dan drugs.com.

\section{Rancangan Penelitian}

Penelitian yang di diawali dengan menyusun proposal kemudian https://doi.org/10.33759/jrki.v4i1.222 
merancang surat pengajuan penelitian di RS Tk II dr. Soepraoen Malang. Setelah disetujui dilakukan penelitian dengan mengolah data rekam medis pada bulan Oktober - Desember 2020. Data rekam medis terlebih dahulu dipilih berdasarkan kriteria inklusi, kemudian direkapitulasi untuk mengetahui gambaran interaksi obat penyakit jantung koroner dengan sindrom metabolik pada pasien rawat jalan. Hasil rekapitulasi data interaksi obat dilakukan pengolahan data menggunakan aplikasi Drug Interaction Checker di aplikasi MEDSCAPE dan drugs.com.

Tabel I. Karakteristik Pasien Penyakit Jantung Koroner dengan Sindrom Metabolik

\begin{tabular}{cccc}
\hline $\begin{array}{c}\text { Karakteristik } \\
\text { Pasien }\end{array}$ & Parameter & N & Persentase (\%) \\
\hline \multirow{2}{*}{ Jenis Kelamin } & Laki-laki & 52 & $58,4 \%$ \\
& Perempuan & 37 & $41,6 \%$ \\
\hline \multirow{2}{*}{ Usia } & $40-49$ tahun & 7 & $7,9 \%$ \\
& $50-59$ tahun & 19 & $21,4 \%$ \\
& $60-69$ tahun & 35 & $39,3 \%$ \\
& $70-79$ tahun & 25 & $28,1 \%$ \\
& $80-89$ tahun & 3 & $3,3 \%$ \\
\hline
\end{tabular}

Pada tabel di atas, menunjukkan bahwa angka kejadian pasien Penyakit Jantung Koroner dengan sindrom metabolik di RS Tk II dr. Soepraoen 63

\section{HASIL DAN PEMBAHASAN}

Responden dalam penelitian ini merupakan pasien yang termasuk dalam kriteria inklusi yaitu pasien dengan diagnose Penyakit Jantung Koroner dan dengan riwayat sindrom metabolik seperti hipertensi, diabetes mellitus, dan kolesterol dengan ketentuan umur $\geq 40$ tahun, periode 3 bulan pada bulan Oktober - Desember 2020 sebanyak 89 data rekam medis. Berdasarkan 89 data rekam medis tersebut didapatkan data seperti yang tertera pada tabel.

\section{Demografi Pasien}


diderita pada rentang usia 60-69 tahun $(39,3 \%)$.

\section{Data Khusus}

Tabel II. Diagnosa dengan Sindrom Metabolik Penyakit Jantung Koroner Di RS Tk II dr. Soepraoen Malang

\begin{tabular}{llll}
\hline No. & Sindrom Metabolik & Jumlah & Persentase (\%) \\
\hline 1. & Hipertensi & 54 & $62,8 \%$ \\
2. & Diabetes Mellitus & 14 & $16,3 \%$ \\
3. & Dislipidemia (kolesterol) & 18 & $20,9 \%$ \\
\hline \multicolumn{2}{c}{ Total } & $\mathbf{8 6}$ & $\mathbf{1 0 0 \%}$ \\
\hline
\end{tabular}

Hasil data yang didapat Penyakit Jantung Koroner, paling menunjukkan bahwa banyak terjadi banyak terjadi adalah pasien dengan komplikasi yang terjadi pada pasien hipertensi 54 pasien $(62,79 \%)$.

Tabel III. Gambaran Umum Data Rekam Medis Pada Pasien Penyakit Jantung Koroner dengan Sindrom Metabolik di RS Tk II dr. Soepraoen Malang

\begin{tabular}{rccc}
\hline \multirow{2}{*}{ Gambaran Umum } & \multicolumn{2}{c}{ Parameter } & \multirow{2}{*}{ Persentase (\%) } \\
\cline { 2 - 3 } & jumlah & $\mathbf{N}$ & \\
\hline \multirow{2}{*}{ Jumlah Obat } & $2-5$ obat & 85 & $95,5 \%$ \\
& $>5$ obat & 4 & $4,5 \%$ \\
\hline Total & & $\mathbf{8 9}$ & $\mathbf{1 0 0 \%}$ \\
\hline
\end{tabular}

Peresepan pada pasien Penyakit sehingga memungkinkan untuk terjadi Jantung Koroner dengan sindrom interaksi obat. Pada tabel menunjukkan metabolik di RS Tk II dr. Soepraoen bahwa jumlah obat paling banyak di Malang periode oktober-desember 2020 gunakan yaitu 2 - 5 obat macam obat pasien mendapatkan lebih dari satu obat $(95,50 \%)$. 
Tabel IV. Golongan Obat Pasien Penyakit Jantung Koroner dengan Sindrom Metabolik

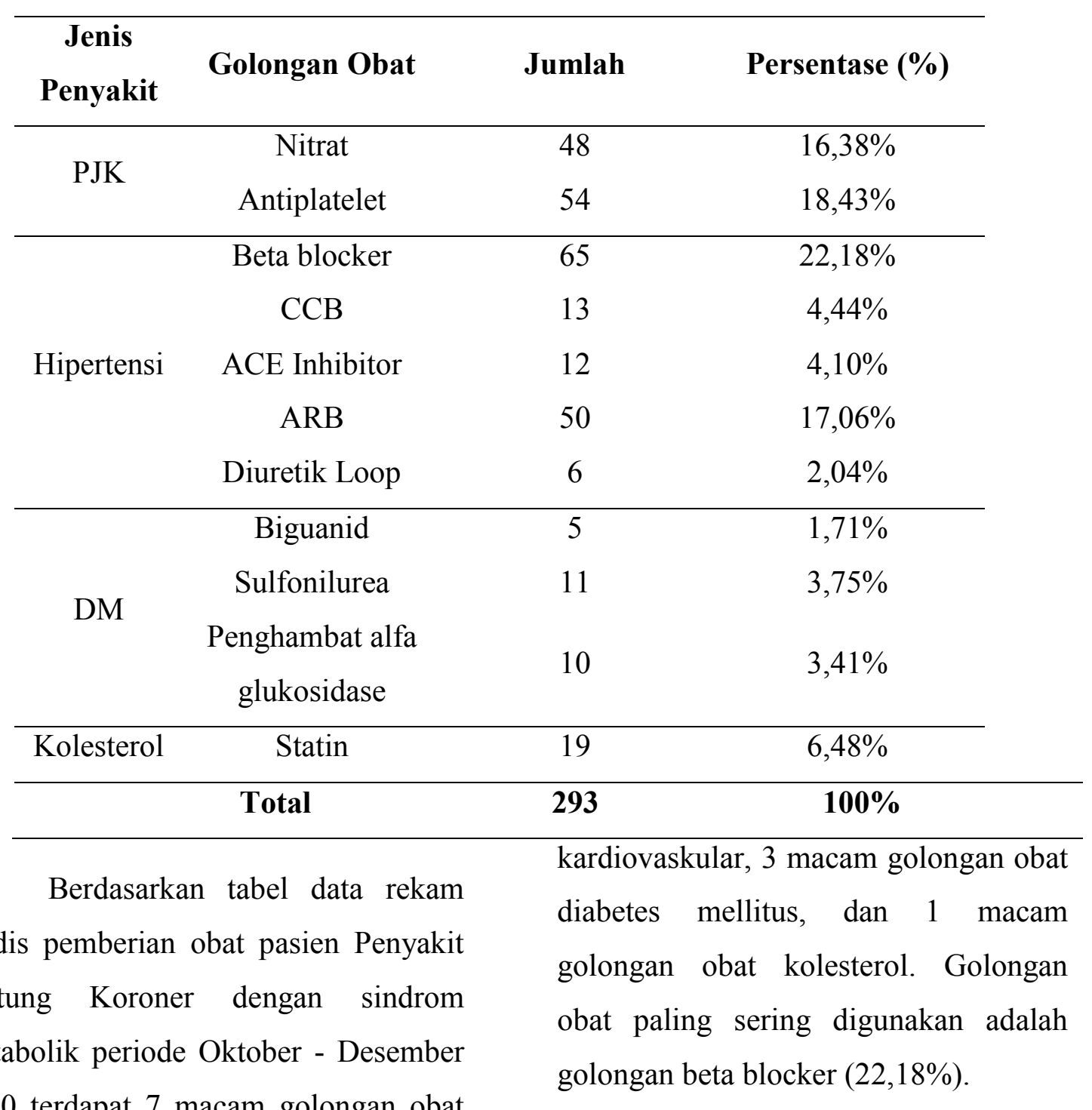

2020 terdapat 7 macam golongan obat

Tabel V. Kandungan Obat Yang Digolongkan Berdasarkan Penyakit pada Pasien

\begin{tabular}{cccc}
\hline \multirow{2}{*}{ Penyakit } & $\begin{array}{c}\text { Kandungan } \\
\text { Obat }\end{array}$ & Jumlah & Persentase (\%) \\
\hline \multirow{2}{*}{ PJK } & ISDN & 48 & $16,38 \%$ \\
& Aspirin & 23 & $7,84 \%$ \\
& Clopidogrel & 31 & $10,58 \%$ \\
\hline \multirow{2}{*}{ Hipertensi } & Bisoprolol & 65 & $22,18 \%$ \\
& Nifedipine & 4 & $1,36 \%$ \\
& Amlodipine & 9 & $3,07 \%$
\end{tabular}




\begin{tabular}{cccc} 
& Ramipril & 12 & $4,09 \%$ \\
& Candesartan & 36 & $12,29 \%$ \\
& Valsartan & 11 & $3,75 \%$ \\
& Telmisartan & 3 & $1,02 \%$ \\
& Furosemide & 6 & $2,04 \%$ \\
\hline \multirow{2}{*}{ Kolesterol } & Atorvastatin & 6 & $2,04 \%$ \\
& Simvastatin & 13 & $4,43 \%$ \\
\hline \multirow{2}{*}{ DM } & Metformin & 5 & $1,70 \%$ \\
& Acarbose & 10 & $3,41 \%$ \\
\hline & Glimepiride & 11 & $3,75 \%$ \\
\hline
\end{tabular}

Berdasarkan tabel diatas, yang diberikan kepada 89 pasien pemberian obat pasien rekam medis Penyakit Jantung Koroner dengan pada pasien Penyakit Jantung Koroner sindrom metabolik. Kandungan obat dengan sindrom metabolik terdapat 14 yang paling sering digunakan yaitu kandungan obat yang digolongkan bisoprolol (22,18\%) dengan indikasi berdasarkan penyakit masing-masing penyakit Hipertensi.

Tabel VI. Klasifikasi Interaksi Obat Penyakit Jantung Koroner dengan Sindrom Metabolik di RS Tk II dr. Soepraoen Malang

\begin{tabular}{lccccc}
\hline \multicolumn{1}{c}{ Interaksi Obat } & Mekanisme & Klasifikasi & Fase IO & Jumlah & $\%$ \\
\hline Aspirin + Ramipril & Farmakodinamik & Moderate & Antagonis & 3 & $2,5 \%$ \\
Aspirin + & Farmakodinamik & Moderate & Sinergis & 10 & $8,3 \%$ \\
Clopidogrel & Farmakokinetik & & & & \\
Aspirin + Bisoprolol & Farmakodinamik & Minor & Antagonis & 22 & 18,33 \\
& & & & & $\%$ \\
Aspirin + & Farmakodinamik & Moderate & Antagonis & 12 & $10 \%$ \\
Candesartan & & & & & \\
Aspirin + Furosemide & Farmakodinamik & Minor & Antagonis & 2 & $1,67 \%$ \\
Aspirin + & Farmakodinamik & Moderate & Antagonis & 5 & $4,16 \%$ \\
Glimepiride & & & & &
\end{tabular}




$\begin{array}{llllll}\text { Aspirin }+ \text { Amlodipin } & \text { Farmakodinamik } & \text { Moderate } & \text { Antagonis } & 3 & 2,5 \% \\ \text { Aspirin }+ & \text { Farmakodinamik } & \text { Moderate } & \text { Antagonis } & 3 & 2,5 \%\end{array}$

Telmisartan

$\begin{array}{lllccc}\text { Aspirin }+ \text { nifedipine } & \text { Farmakodinamik } & \text { Moderate } & \text { Antagonis } & 2 & 1,67 \% \\ \text { Clopidogrel }+ & \text { Farmakodinamik } & \text { Moderate } & \text { Sinergis } & 4 & 3,3 \% \\ \text { atorvastatin } & \text { Farmakokinetik } & & & & \\ \text { ISDN + Ramipril } & \text { Farmakodinamik } & \text { Moderate } & \text { Antagonis } & 8 & 6,66 \% \\ \text { Bisoprolol }+ & \text { Farmakodinamik } & \text { Moderate } & \text { Sinergis } & 6 & 5 \% \\ \text { Glimepiride } & & & & & \\ \text { Bisoprolol }+ & \text { Farmakodinamik } & \text { Moderate } & \text { Antagonis } & 12 & 10 \% \\ \text { amlodipine } & & & & & \end{array}$

Bisoprolol $+\quad$ Farmakodinamik $\quad$ Moderate Antagonis $\quad 8 \quad 6,66 \%$

Furosemide

Bisoprolol $+\quad$ Farmakodinamik $\quad$ Moderate $\quad$ Sinergis $\quad 6 \quad 5 \%$

valsartan

Bisoprolol $+\quad$ Farmakodinamik $\quad$ Moderate $\quad$ Sinergis $\quad 4 \quad 3,3 \%$

nifedipine

Nifedipine $+\quad$ Farmakodinamik $\quad$ Moderate $\quad$ Antagonis $2 \quad 1,67 \%$

simvastatin

Ramipril +

Moderate $\quad$ Sinergis $\quad 1 \quad 0,83 \%$

glimepiride Farmakodinamik

$\begin{array}{lllll}\text { Ramipril }+\quad \text { Farmakodinamik } & \text { Minor } & \text { Sinergis } & 1 & 0,83 \%\end{array}$

amlodipine

Ramipril + $\quad$ Farmakodinamik $\quad$ Moderate $\quad$ Sinergis $\quad 5 \quad 4,16 \%$

Furosemide

Amlodipine $+\quad$ Farmakodinamik $\quad$ Moderate $\quad$ Antagonis $\quad 1 \quad 0,83 \%$ atorvastatin

Dari tabel diatas dapat terjadi interaksi obat adalah aspirin disimpulkan bahwa yang paling banyak dengan bisoprolol yang diklasifikasikan 
sebagai interaksi minor dengan persentase $18,33 \%$. Aspirin merupakan obat kardiovaskular golongan antiplatelet sedangkan bisoprolol merupakan golongan beta blocker. Interaksi dari kedua obat ini dapat menurunkan efek bisoprolol dalam menurunkan tekanan darah dan memiliki mekanisme farmakodinamik dengan fase interaksi obat termasuk kedalam antagonis.

Tabel VII. Kejadian Interaksi Obat Berdasarkan Klasifikasi Keparahan Pada Pasien Penyakit Jantung Koroner

\begin{tabular}{|c|c|c|c|}
\hline No. & Klasifikasi & Jumlah & Persentase $(\%)$ \\
\hline 1. & Minor & 3 & $14,28 \%$ \\
\hline 2. & Moderate & 18 & $85,72 \%$ \\
\hline 3. & Mayor & - & - \\
\hline & Total & 21 & $100 \%$ \\
\hline
\end{tabular}

Dapat dilihat pada tabel vii menunjukkan tingkat signifikansi interaksi obat yang paling banyak yaitu level moderate $(85,71 \%)$. Pada tingkat moderate, efek yang terjadi cukup signifikan secara klinis, dan dianjurkan untuk menghindari kombinasi, biasanya hanya menggunakannya dalam keadaan khusus.

Tabel VIII. Mekanisme Interaksi Obat Pada Pasien Penyakit Jantung Koroner dengan Sindrom Metabolik

\begin{tabular}{lrcc}
\hline No. & Klasifikasi & Jumlah & Persentase (\%) \\
\hline 1. & Farmakodinamik & 21 & $91,30 \%$ \\
2. & Farmakokinetik & 2 & $8,70 \%$ \\
\hline \multicolumn{2}{c}{ Total } & $\mathbf{2 3}$ & $\mathbf{1 0 0 \%}$ \\
\hline
\end{tabular}

Berdasarkan tabel diatas, farmakodinamik (91,30\%). Hal tersebut mekanisme interaksi yang paling menunjukkan bahwa potensi interaksi banyak teridentifikasi adalah interaksi lebih banyak terjadi pada tingkat 
reseptor, tempat kerja yang sama sehingga efek aditif (efek berlebihan), sinergis (saling memperkuat), atau antagonis (efek yang berlawanan).

Tabel IX. Interaksi Obat Pada Pasien Penyakit Jantung Koroner dengan Sindrom Metabolik

\begin{tabular}{cccc}
\hline $\begin{array}{c}\text { Jumlah } \\
\text { pasien }\end{array}$ & Berpotensi IO & Tidak berpotensi IO & Persentase (\%) \\
\hline \multirow{2}{*}{89} & 82 & - & $92,13 \%$ \\
& - & 7 & $7,87 \%$ \\
\hline \multicolumn{3}{r}{ Total } & $\mathbf{1 0 0 \%}$ \\
\hline
\end{tabular}

Berdasarkan tabel diatas yaitu merokok yang dapat menyebabkan menunjukkan bahwa pasien Penyakit kerusakan jantung (Karyatin, 2019).

Jantung Koroner dengan Sindrom Metabolik di RS Tk II dr. Soepraoen Malang periode Oktober-Desember 2020 berpotensi mengalami interaksi obat sebanyak 82 pasien (92,13\%).

Dari 89 data rekam medis periode bulan Oktober sampai dengan bulan Desember 2020, angka kejadian Penyakit Jantung Koroner banyak terjadi pada pasien dengan jenis kelamin laki-laki sebanyak 52 pasien $(58,42 \%)$ dibandingkan perempuan sebanyak 37 pasien $(41,57 \%)$ dimana pasien diagnose Penyakit Jantung Koroner lebih banyak ditemukan pada pasien laki-laki karena laki-laki cenderung hidup dengan faktor resiko Penyakit Jantung Koroner salah satunya
Peresepan pada pasien Penyakit Jantung Koroner dengan sindrom metabolik di RS Tk II dr. Soepraoen Malang periode oktober - desember 2020 pasien mendapatkan lebih dari satu obat sehingga memungkinkan untuk terjadi interaksi obat. Pada peresepan obat Penyakit Jantung Koroner menunjukkan bahwa jumlah obat paling banyak di gunakan yaitu 2 5 obat macam obat $(95,50 \%)$. Hal tersebut disebabkan karena setiap pasien memiliki perbedaan kondisi atau keparahan penyakit yang sedang dialami dan adanya penyakit penyerta seperti hipertensi, diabetes mellitus dan kolesterol. Adanya perbedaan keparahan penyakit dan adanya https://doi.org/10.33759/jrki.v4i1.222 
penyakit penyerta, tentu golongan obat dan jenis obatnya pun berbeda. Tingkat keparahan interaksi obat merupakan hal penting dalam menilai risiko dan keuntungan dalam terapi. Tingkat keparahan mayor memiliki efek yang berpotensi dapat mengancam nyawa atau dapat menyebabkan kerusakan permanen. Tingkat keparahan moderate memiliki efek yang dapat menyebabkan penurunan status klinis pasien. Sedangkan untuk tingkat keparahan minor memiliki efek yang ringan sehingga tidak terlalu mengganggu terapi dan tidak memerlukan terapi tambahan (Hanutami NP \& Lestari Dandan, 2013). Keparahan penyakit dan adanya penyakit penyerta mempengaruhi interaksi obat dalam satu resepnya.

Penelitian ini menunjukkan persentase interaksi obat yang paling banyak adalah interaksi farmakodinamik sebanyak 21 kasus $(91,30 \%)$ dan 2 kasus farmakokinetik $(8,70 \%)$. Data menunjukkan tingkat keparahan interaksi paling banyak adalah moderate sebesar 18 kasus $(85,72 \%)$. Untuk tingkat keparahan minor sebesar 3 kasus (14,28\%). Secara terotitis, Interaksi farmakokinetik terjadi apabila salah satu obat dapat mempengaruhi absorpsi, distribusi, metabolisme, dan ekresi obat yang lain, sehingga kadar obat kedua plasma meningkat atau menurun. Sedangkan interaksi farmakodinamik adalah interaksi antara obat-obat yang mempunyai khasiat atau efek samping yang berlawanan (Katzung, 2018).

Berdasarkan penelitian ini menunjukkan interaksi yang paling banyak adalah aspirin dengan bisoprolol yang diklasifikasikan sebagai interaksi minor dengan persentase $18,33 \%$, yang termasuk kedalam fase antagonis. Bisoprolol merupakakan golongan dari beta-blocker yang merupakan lini pertama digunakan untuk mengendalikan denyut jantung dan mengurangi atau mencegah timbulnya gejala pada gangguan kardiovaskuler arteri koroner stabil. Pada kondisi post miokard infark, beta-blocker mampu mengurangi resiko kematian sebesar 20$25 \%$. Penggunaan beta-blocker dapat menurunkan denyut jantung pada pasien atrial fibrilasi (Sari, 2020).

Interaksi obat antara aspirin dengan bisoprolol ini termasuk fase antagonis dikarenakan interaksi dari kedua obat tersebut dapat meningkatkan efek bisoprolol dalam menurunkan tekanan darah, dimana definisi interaksi

https://doi.org/10.33759/jrki.v4i1.222 
antagonis yaitu bila obat yang berinteraksi memiliki efek farmakologi yang berlawanan sehingga mengakibatkan pengurangan hasil yang diinginkan dari satu atau lebih obat. Berdasarkan mekanismenya aspirin dapat menghambat biosintesis prostaglandin yang terlibat dalam aktivitas hipertensi bisoprolol, yang termasuk kedalam mekanisme farmakodinamik Prostaglandin merupakan vasodilator kuat yang berperan penting dalam pengaturan aliran darah yang berakibat terhambatnya biosintesis prostaglandin terjadi peningkatan tekanan darah. Bisoprolol berperan mencegah pengikatan epinefrin endogen dan norepinefrin pada reseptor beta adrenergik tidak dapat bekerja secara maksimal (Nurdiyanti et al., 2020). Contoh obat lain yang termasuk fase antagonis adalah aspirin dengan ramipril. Menurut literature pada aplikasi MEDSCAPE, pemberian bersama antara aspirin dengan ramipril dapat menyebabkan penurunan fungsi ginjal yang signifikan. Golongan NSAID (aspirin) dapat mengurangi efek dari golongan ACE inhibitor (ramipril) karena kemampuan golongan NSAID yang dapat mengurangi sintesis prostaglandin vasodilatasi ginjal. Oleh sebab itu perlu pemantauan dengan cermat, mengenai penakaran dosis yang tepat untuk mengurangi kemerosotan fungsi ginjal, khususnya dengan dosis tinggi aspirin pada orang yang sudah lanjut usia (MEDSCAPE, 2021).

Interaksi obat antara aspirin dengan candesartan dan aspirin dengan telmisartan diklasifikasikan kedalam moderate dengan mekanisme yang terjadi farmakodinamik dan fase interaksi obatnya termasuk antagonis. Candesartan dan telmisartan merupakan satu golongan obat yaitu golongan ARB. NSAIDs dapat menyebabkan penumpukan cairan, yang dapat mempengaruhi tekanan darah. Kedua obat ini meningkatkan serum kalium, namun untuk pasien usia lanjut dapat mengakibatkan kemerosotan fungsi ginjal, hal tersebut dapat membahayakan fungsi renal (Drugs.com, 2021). Dari beberapa interaksi obat yang termasuk fase antagonis jika obat yang berinteraksi memiliki efek yang berlawanan sehingga menyebabkan pengurangan hasil yang diinginkan dan dilakukan pemantauan untuk menghindari adanya terapi tambahan.

https://doi.org/10.33759/jrki.v4i1.222 


\section{KESIMPULAN}

Berdasarkan hasil penelitian mengenai gambaran interaksi obat Penyakit Jantung Koroner dengan sindrom metabolik pada pasien rawat jalan di RS Tk II dr. Soepraoen Malang periode Oktober - Desember 2020, dapat disimpulkan bahwa 82 resep berpotensi mengalami interaksi obat dimana tingkat signifikansi interaksi obat paling banyak yaitu level moderate $(81,48 \%)$ dan interaksi obat paling banyak yaitu interaksi antara aspirin dengan bisoprolol yang tergolong interaksi minor $(17,74 \%)$. Jenis obat yang paling sering digunakan yaitu bisoprolol $(22,18 \%)$ dan golongan obat paling sering digunakan adalah beta blocker $(22,18 \%)$ sehingga dapat dikatakan sesuai dengan jenis obat yang paling sering digunakan.

\section{UCAPAN TERIMAKASIH}

Peneliti ingin mengucapkan terima kasih kepada berbagai pihak yang telah membantu terwujudnya penelitian ini:

1. Rektor ITSK RS Tk II dr. Soepraoen Malang
2. Ketua LPPM \& staff ITSK RS Tk II dr. Soepraoen Malang

\section{DAFTAR PUSTAKA}

Dokter, P., Kardiovaskular, S., \& Ketiga, E. (2015). Pedoman Tatalaksana Sindrom Koroner Akut Edisi Ketiga.

Hanutami, B. (2019). identifikasi potensi interaksi antar obat pada resep umum di apotek kimia farma 58 kota bandung bulan april 2019. 17(April), 57-64.

Hanutami NP, B., \& Lestari Dandan, K. (2013). Identifikasi Potensi Interaksi Antar Obat Pada Resep Umum Di Apotek Kimia Farma 58 Kota Bandung Bulan April 2019. Farmaka, 4(April), 1-15.

Imaligy, ervinaria uly. (2014). Gagal Jantung pada Geriatri (Vol. 41, Issue 1).

Karyatin, K. (2019). Faktor-Faktor Yang Berhubungan Dengan Kejadian Penyakit Jantung Koroner. Jurnal Ilmiah Kesehatan, 11(1), 37-43. https://doi.org/10.37012/jik.v11i1. 66 
Katzung, B. G. (2018). Basic and Clinical Pharmacology Fourteenth Edition / Edited by: Bertram G. Katzung (18th ed.).

Kuncoro, B., \& Yanti, Y. (2019). Evaluation Of Coronary Heart Drug Interactions In Patients Hospitaled In Tangerang General Hospital 2017. VI(1), 38-46.

Nurdiyanti, R., Furdiyanti, N. H., \& Dyahariesti， N. (2020). Kajian Interaksi Bisoprolol Pada Pasien Rawat Inap Di Rumah Sakit Islam
Sultan Agung Semarang Periode 2018. Indonesian Journal of Pharmacy and Natural Product.

Sari, O. M. (2020). Studi Penggunaan Obat Golongan Beta-Blocker Pada Pasien Rawat Inap Rumah Sakit Ansari Saleh Banjarmasin. Jurnal Farmasi Udayana, 9(2), 123. https://doi.org/10.24843/jfu.2020.v 09.i02.p07 